\title{
THE TEST OF COMPETING MODELS FOR THE PREHISTORIC PEOPLING OF THE AZAPA VALLEY, NORTHERN CHILE, USING MATRIX CORRELATIONS
}

\author{
MODELOS ALTERNATIVOS PARA EXPLICAR EL POBLAMIENTO \\ PREHISTÓRICO DEL VALLE DE AZAPA, NORTE DE CHILE, MEDIANTE \\ ANÁLISIS DE CORRELACIÓN DE MATRICES
}

\author{
Richard C. Sutter ${ }^{1}$
}

\begin{abstract}
This study reports biodistances from nonmetric dental traits for eleven mortuary samples -an Andean Paleoindian sample, a Tiwanaku sample, and nine from the Azapa Valley- to test three models for the prehistoric population dynamics of the Azapa Valley, Chile, using matrix correlation analysis of hypothetical design matrices. These models include: (1) Tiwanaku colonization during the Middle Period, (2) simple gene flow over time, and (3) a modified gene flow model with coastal groups demonstrating genetic continuity while diverging from valley populations. The Tiwanaku sample demonstrates significant biodistances with five of the nine Azapa Valley samples, and large but nonsignificant differences with all but the late Desarrollo Regional Gentilar sample from Azapa-8. Inland samples from the Azapa Valley generally become more similar to the Tiwanaku sample through time suggesting gene flow, while coastal samples of the region demonstrate a degree of epigenetic coherence. The results of Mantel tests for each of the three design matrices indicates that the Tiwanaku and simple gene flow models produce nonsignificant and low correlations with the biodistance matrix while the gene flow with coastal divergence model produces significant results. The implications of these results are discussed.
\end{abstract}

Key words: Biodistance analysis, skeletal remains, matrix correlation.

En este trabajo se analizan distancias biológicas obtenidas de rasgos no-métricos dentales extraídas de once muestras mortuorias - una muestra de paleoindios andinos, otra de Tiwanaku y nueve del valle de Azapa- para poner a prueba tres modelos que expliquen las dinámicas prehistóricas poblacionales en el valle de Azapa, Chile, mediante análisis de correlación de matrices hipotéticas. Estos modelos incluyen: (1) la colonización durante el período Medio por los Tiwanaku, (2) flujo genético a través del tiempo, (3) y un modelo de flujo genético donde los grupos costeros muestran continuidad genética mientras divergen de poblaciones del valle, las cuales reciben flujo genético del altiplano. La muestra de Tiwanaku está separada por distancias biológicas significativas con cinco de las nueve muestras del valle de Azapa, y distancias grandes pero no significativas con las demás muestras, exceptuando la muestra Gentilar del desarrollo regional tardío de Azapa-8. Las muestras del valle se vuelven más similares a la muestra de Tiwanaku a través del tiempo, lo que sugiere flujo genético, mientras que las muestras costeras manifiestan una coherencia epigenética. Los resultados de la prueba de Mantel para cada uno de los tres modelos indica que los modelos de colonización tiwanakoide y de flujo genético no producen resultados significativos, mientras que el modelo de flujo genético con divergencia costera sí lo hace. Se discuten las consecuencias de estos resultados en relación con publicaciones anteriores.

Palabras claves: análisis de distancias biológicas, restos esqueletales, análisis de correlación de matrices.

The prehistory of the Azapa Valley has been of interest to scholars for nearly a century now, and has included examinations of both cultural developments and prehistoric population dynamics. One of the topics most thoroughly investigated by both archaeologists biological anthropologists working in northern Chile, is the relationship between prehistoric inhabitants of the Azapa Valley with populations from the adjacent altiplano to the east. Of particular interest has been their relationship to the Middle Period Tiwanaku of Bolivia. Historically archaeologists such as Uhle (1919), Bird (1943), and Mostny (1944) established relative chronological sequences using ceramics found in the region and their relationship to those from Tiwanaku, while subsequent investigators proposed that the Tiwanaku sent ethnic colonists to the Azapa Valley according to the classic model of verticality (i.e., zonal complementarity) proposed by Murra $(1967,1972)$. Following the

\footnotetext{
1 Department of Anthropology Indiana Purdue University Fort Wayne 2101 E. Coliseum Blvd. Fort Wayne, IN 46805-1499 U.S.A.SutterR@ipfw.edu.
} 
archaeologists lead, subsequent bioarchaeological investigations for the Azapa Valley focused on determining whether phenotypic evidence exists for prehistoric ethnically altiplano colonists. To date, numerous biodistance have been conducted, but no consensus has been reached regarding the presence of ethnically Tiwanaku colonists in the prehistoric Azapa Valley, Chile. This investigation endeavors to test three competing models explaining prehistoric population dynamics for the Azapa Valley, Chile, with particular focus on the Middle Period, using nonmetric tooth and cusp traits and matrix correlation analysis among generated biodistances and the design matrices for each of the three competing models.

\section{Prehistory of Azapa Valley}

Largely based upon lithic similarities in the coastal valley and adjacent highlands, archaeologists working in northern Chile argue that the early Archaic Period (8,000-1,000 B.C.) inhabitants of the Azapa Valley where likely transhumant hunter-gatherers who probably frequented the adjacent highlands to the east (Santoro 1989, 1993). Among the earliest human remains of the Azapa Valley from sites Acha-2 and Acha-3, there is ample evidence for the exploitation of marine resources in the form of fish and shellfish remains, in addition to human remains exhibiting auditory exostoses -a bony inner ear pathology associated with frequent ear infections caused by cold water diving (Arriaza and Muñoz 1993; Standen et al. 1997). Eventually, these early Archaic Period populations began to focus their economic activities almost exclusively on maritime resources and began to practice artificial mummification (Arriaza 1994, 1995; Guillén 1992). Phenotypic, cultural, and molecular evidence has been used to suggest that these people-culturally referred to as the Chinchorro- had their genetic and cultural origins among either the earlier Andean Paleoindians (Sutter 1997, 1999:82, 2005a, 2005c), or among Amazonian populations (Moraga et al. 2001; Rivera 1975, 1984, 1997, 1991; Rivera and Rothhammer 1986; Rothhammer and Silva 1989, 1992; Rothhammer et al. 1984, 2002).

The Formative Period (1,000 B.C.-A.D. 500) in the Azapa Valley begins with the appearance of ceramics, settled village life, and agriculture. Sandtempered ceramics are found in the burial contexts and middens of Faldas del Morro (Dauelsberg 1985) and El Laucho (Focacci 1974) coastal sites of northern Chile, where inhabitants largely exploited maritime resources. The Azapa (1,000800 B.C.) and Alto Ramírez (800 B.C.-A.D. 500) phase sites are located a few kilometers inland. Inhabitants of these sites practiced a mixed agropastoral and maritime subsistence (Muñoz 1981, 1983a, b, 1989; Santoro 1980a, b, c). Although some scholars contend that the appearance of fibertempered ceramics contemporaneous with those from the altiplano Chiripa site, and textiles with altiplano Pukara motifs are evidence for Formative Period altiplano colonists or population movements into the Azapa Valley (Kolata 1993:76; Muñoz 1983b,1989; Muñoz 1983; Rivera 1984,1991; Rothhammer et al. 1989:406, 2002:263; Santoro 1980b; Varela and Cocilovo 2002:264), others have suggested that both the genetic and cultural origins of Formative Period populations is among the preceding Chinchorro (Rothhammer and Santoro 2001; Sutter 1997, 1999, 2000, 2005a, b).

The Middle Period (A.D. 500-1,100) in northern Chile is defined by the presence both of Tiwanaku V and Tiwanaku-inspired Azapa Valley Cabuza, Loreto Viejo, and Maitas-Chiribaya ceramics (Berenguer and Dauelsberg 1989). The prevailing opinion among archaeologists working in northern Chile is that Cabuza and MaitasChiribaya Middle Period sites in the Azapa Valley represent pre-Inka example of altiplano colonies according to Murra's classic model of verticality (Berenguer 1978; Browman 1980, 1984; Focacci 1969a:22, 1981:68; Kolata 1993:76; Lumbreras 1972; Mujica 1985; Mujica et al. 1983; Rivera 1975, 1991). Indeed, Focacci (1981:68) and Berenguer and Dauelsberg (1989) propose that Cabuza ceramics are directly derived from Tiwanaku IV altiplano, populations and that subsequent Maitas-Chiribaya ceramics represent a later derived form of Tiwanaku-derived ceramics that chronologically correspond to Tiwanaku V, while Rivera (1991) and Berenguer et al. (1988) suggest that Azapa Valley burials associated with Loreto Viejo ceramics represent Tiwanaku elite. It should be noted, however, that other scholars have presented calibrated radiocarbon dates for both the Azapa Valley and comparative archaeological evidence from Moquegua. The calibrated dates indicate that these cultural phenomena -while technically beginning during the terminal Middle 
Period- are largely post-Tiwanaku cultural phenomena (Cassman 1997:61; Owen 1993:413420; Sutter 1997:33-36, 2005b:185-186). In any case, Tiwanaku V ceramics and textiles have also been recovered from burials and ceremonial túmulo mounds from coastal valley sites Azapa-6, Azapa-71, Azapa-75, Azapa-141, and Azapa-143 (Berenguer and Dauelsberg 1989; Focacci 1981, 1983; Goldstein 1995; Muñoz 1989). Interestingly, Muñoz (1982:120) notes a remarkable lack of Middle Period coastal sites along the beaches of the Azapa Valley, possibly indicating that the Tiwanaku resettled coastal populations. A number of biodistance studies based upon craniometrics and mtDNA have suggested that Middle Period Azapa Valley populations had their genetic origins among the Tiwanaku (Cocilovo and Rothhammer 1999; Moraga et al. 2005; Rothhammer et al. 1982, 1983, 1986, 1989:406, 2003:272; Varela and Cocilovo 2002:264-265), while others who investigated nonmetric dental (Sutter 1997, 1999, 2000, 2005a, b, 2005c) and cranial data (Guillén 1992; Sutter and Mertz 2004) find that the differences among Middle Period Azapa Valley populations and earlier populations from the valley are nonsignificant, suggesting that detected cultural changes during the Middle Period were largely the result of cultural diffusion rather than population placement by altiplano colonists.

With the demise of the Tiwanaku in the south central Andes, diverse ceramics, burial practices, textiles, and architecture styles begin to emerge throughout the coastal valleys of the region. Within the Azapa Valley this period is referred to as the Desarrollo Regional (A.D. 1,100-1,470) and is defined by the emergence of the San Miguel, Pocoma and Gentilar ceramic traditions (Espoueys et al. 1994; Rivera 1991; Schiappacasse et al. 1989). These traditions are confined to the coastal valley regions of the south central Andes and have no known altiplano counterparts. Grave good and midden analyses reflect a mixed agro-pastoralmaritime subsistence for populations associated with these traditions (Focacci 1982; Muñoz 1983, 1993; Muñoz and Focacci 1985). Recent biodistance analyses suggest that populations dynamics for the Azapa Valley during the Desarrollo Regional was characterized by a marked increase in gene flow into the valley following the collapse of the Tiwanaku (Rothhammer and Santoro 2001; Rothhammer et al. 2002; Sutter 1997; 2005a, b; 2005c), while coastal populations apparently maintained a degree of genetic continuity with earlier coastal peoples (Cocilovo and Rothhammer 1999; Cocilovo et al. 2001; Sutter 1997, 1999:85, 2000:64, 2005b:193-195; Sutter and Mertz 2004:139-140; Varela and Cocilovo 2002:265).

\section{Summary of Biodistance Studies}

While the number of conclusions reached by biodistance studies for the Azapa Valley are numerous and varied -as described above- this investigation focuses on the three most prevalent models for explaining population dynamics for prehistoric inhabitants of the valley, with particular focus on the Middle Period. These models include: (1) Tiwanaku colonization (Cocilovo and Rothhammer 1999; Moraga et al. 2005; Rothhammer et al. 1982, 1983, 1986, 1989:406, 2003:272) (Figure 1), (2) gradual gene flow into the valley from the adjacent altiplano to the east (Guillén 1992; Rothhammer and Santoro 2001; Rothhammer et al. 1983, 1984, 2002) (Figure 2 ), and (3) a modified version of the gene flow model which posits that inland agricultural populations of the Azapa Valley received low levels of gene flow from the altiplano, while coastal populations of the region exhibited a degree of genetic continuity with their Archaic Period Chinchorro ancestors (Sutter 1997, 1999:85, 2000:64, 2005b:193-195; Sutter and Mertz 2004:139-140; Varela and Cocilovo 2002:265) (Figure 3). The assumptions of each of these models are used to develop hypothetical design matrices for testing against biodistance analyses as described in the subsequent section.

\section{Materials and Methods}

A total of 11 mortuary samples are examined by this study (Table 1). The first is the Andean Paleoindian sample and consists of the dental frequencies for human remains from the Andes predating 8,000 calibrated radiocarbon years before present. Sample composition can be found in Sutter (2005c). Although the wide geographic distribution of remains used for this sample is problematic, the paucity of human remains from the Andes predating 8,000 years before present makes it necessary to combine these early human remains. Further, 


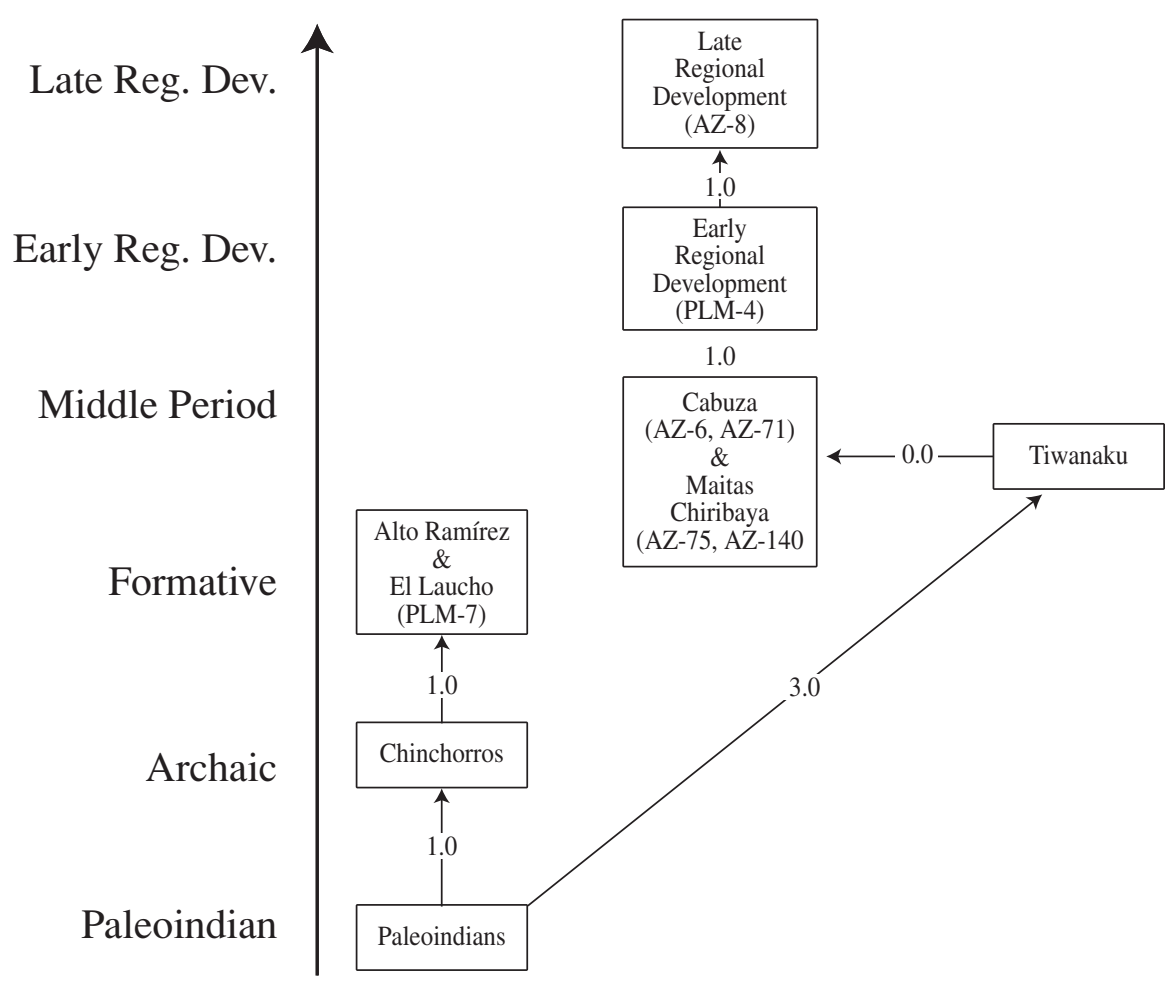

Figure 1. Graphic depiction of the design matrix for the model of large scale migration of Tiwanaku colonization into the prehistoric Azapa Valley, Chile. Hypothetical biodistances are represented by numerical values between each of the samples.

Representación gráfica del diseño de matriz para el modelo migratorio de colonización Tiwanaku en el valle de Azapa, Chile, de escala mayor. Las biodistancias hipotéticas están representadas por valores muméricos en cada muestra.

sample composition for the Andean Paleoindians is consistent with how early human remains have been analyzed by other biodistance studies (Powell 1993, 1995; Powell and Neves 1998; Turner 1983, 1985).

Nine mortuary samples from Azapa Valley sites are analyzed by this study. The Chinchorros represent the Archaic Period population of the Azapa Valley. The remains from four Chinchorro beach sites were combined into a single sample for statistical analyses. These include Morro-1 (Standen 1991), Morro-1/5 (Guillén 1992), Morro-1/6 (Focacci and Chacón 1989), and Playa Miller-8 (Alvarez 1969).

The Formative Period for the Azapa Valley is represented by two samples. The Alto Ramírez sample includes Azapa phase burials from the site Azapa-71 and Alto Ramírez phase burials from the sites Azapa-14, Azapa-70, and Azapa-115. Sites of these phases provide the earliest evidence for coastal valley village life and incipient agriculture within the Azapa Valley (Focacci 1980; Muñoz 1981, 1983, 1989; Santoro 1980a, b, c). All sites included in the Alto Ramírez sample are located inland, 10 to $12 \mathrm{~km}$ from Arica. The Playa Miller-7 sample is from a coastal site that was a contemporaneous Formative period fishing community of the El Laucho cultural tradition, where the earliest pottery of the region was also found (Focacci 1974).

The Middle Period is represented by four samples from the Azapa Valley including two from the Cabuza sites Azapa-6 and Azapa-71 (Focacci 1993) and two samples from the mixed agropastoral Maitas-Chiribaya sites, Azapa-75 and Azapa-140 (Muñoz and Focacci 1985).

Two Azapa Valley samples for the Desarrollo Regional are also examined by this study. The early Desarrollo Regional is represented by human remains from Playa Miller-4 -a coastal fishing 


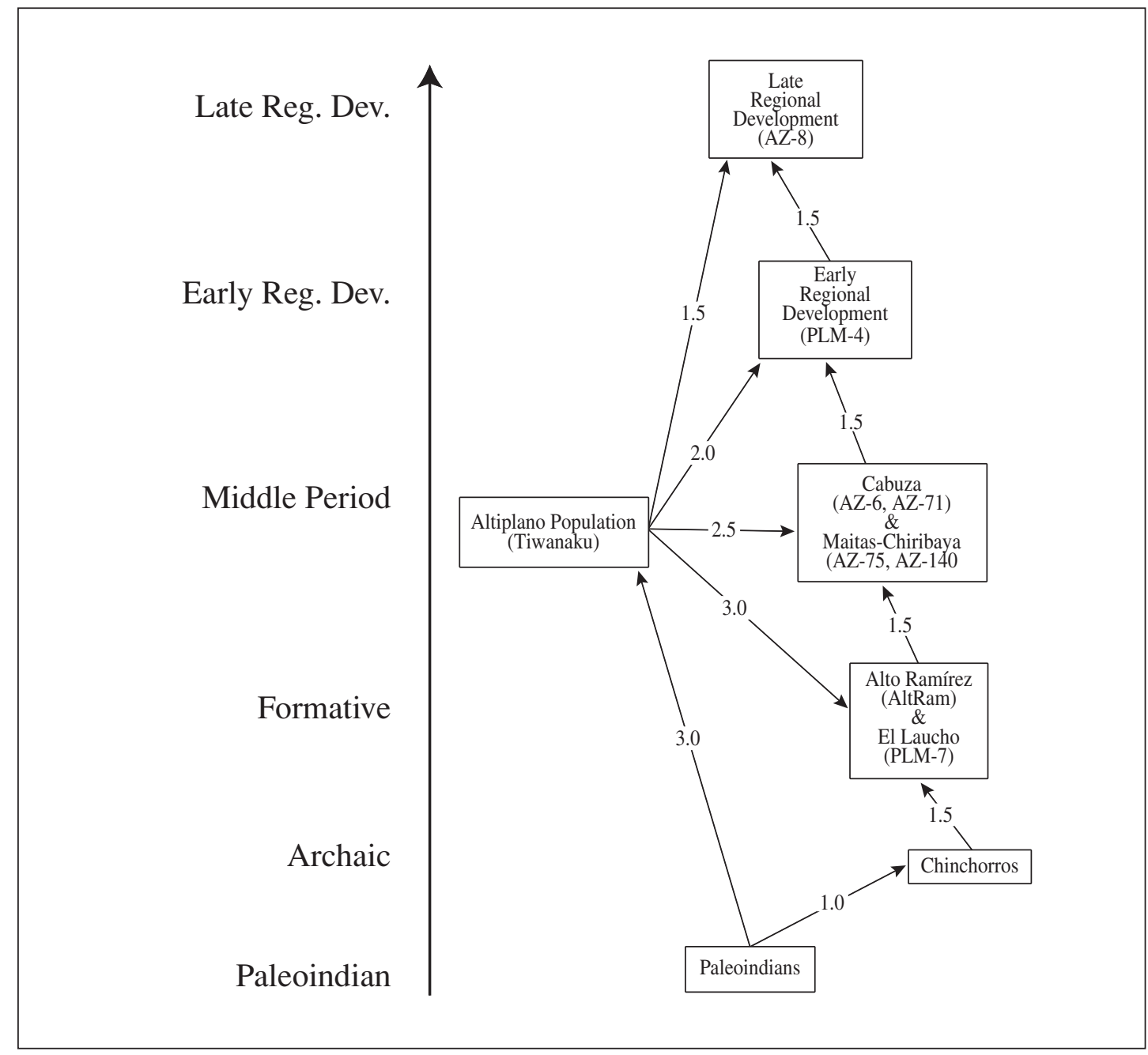

Figure 2. Graphic depiction of the design matrix for the model of simple gene flow from the altiplano for the prehistoric Azapa Valley, Chile. Hypothetical biodistances are represented by numerical values between each of the samples.

Representación gráfica del diseño de matriz para el modelo de flujo genético simple desde el altiplano hacia el valle de Azapa, Chile. Las biodistancias hipotéticas están representadas por valores numéricos en cada muestra.

community primarily associated with San Miguel ceramics (Focacci 1969b, 1974). Azapa-8 is a late Desarrollo Regional Gentilar inland sample (Focacci 1961).

An additional comparative Tiwanaku sample consists of Upper Formative period (500 B.C.-A.D. 500) and Middle Horizon (A.D. 500-1,100) individuals excavated by Bandelier (1910) from the sites Titia-Uayani $(\mathrm{n}=28)$, Tiwanaku $(\mathrm{n}=3)$, and Kea Kolla Chico $(\mathrm{n}=26)$ (also see Stanish and Bauer 2004:193-197). Only those individuals associated with Tiwanaku and pre-Tiwanaku (Qeya) grave goods are included for this sample.

\section{Biodistance Analysis}

For this study, all individual's dentitions were visually inspected and scored by the author of this paper for 31 morphological tooth cusp and root traits (Table 2) using standardized casts and descriptions (Turner et al. 1991). Nonmetric dental traits are highly heritable among living populations (Berry 1978; Biggerstaff 1970, 1973; Escobar et al. 1976; Harris and Bailit 1980; Hassanali 1982; Nichol 1989; Portin and Alvesalo 1974; Scott 1973, 1980; Sofaer et al. 1972a) and have been used to reconstruct genetic relations among both prehistoric 


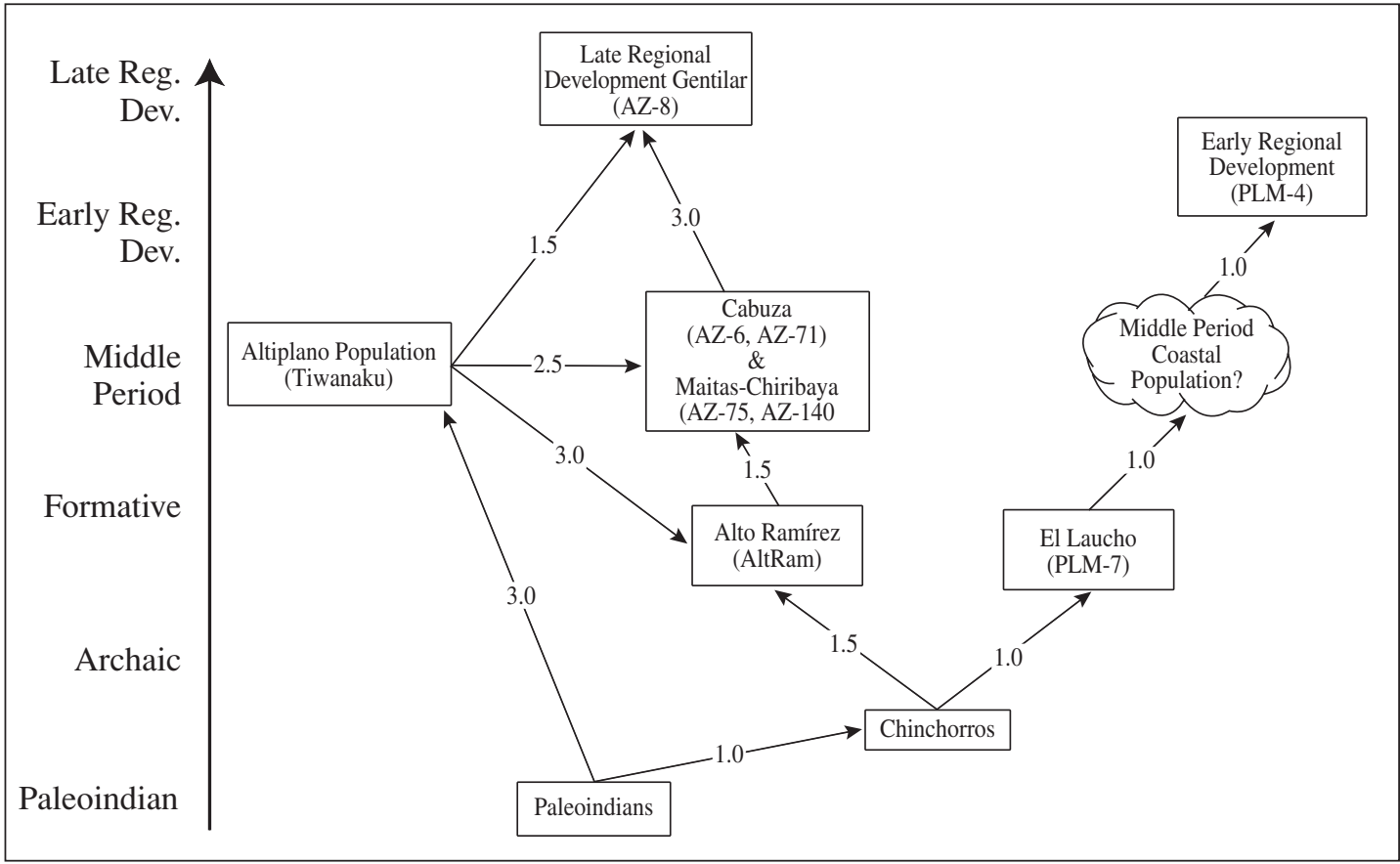

Figure 3. Graphic depiction of the design matrix for the model of divergence of coastal groups and gene flow from the altiplano among valley populations for the prehistoric Azapa Valley, Chile. Hypothetical biodistances are represented by numerical values between each of the samples.

Representación gráfica del diseño de matriz para el modelo de divergencia de grupos costeros y flujo genético desde el altiplano entre poblaciones del valle de Azapa, Chile. Las biodistancias hipotéticas están representadas por valores numéricos en cada muestra.

Table 1. Eleven prehistoric Andean samples examined by this study.

Once muestras andinas prehistóricas examinadas en este estudio.

\begin{tabular}{|c|c|c|c|c|c|}
\hline Sample & $\begin{array}{l}\text { Site(s) Represented } \\
\text { by Sample }\end{array}$ & $\begin{array}{l}\text { Sample } \\
\text { Size }\end{array}$ & $\begin{array}{l}\text { Cultural } \\
\text { Affiliation }\end{array}$ & Location of Site(s) & Time Period \\
\hline PALEO & Paleoindian & 34 & Paleoindian & Throughout Andes & Paleoindian pre-8,000 cal B.P. \\
\hline $\mathrm{CHINCH}$ & $\begin{array}{l}\text { Morro-I, Morro-V, } \\
\text { Morro-VI, PLM8 }\end{array}$ & 84 & Chinchorro & Azapa, Coast & Archaic 3,000 - 1,000 B.C. \\
\hline PLM7 & Playa Miller-7 & 62 & El Laucho & Azapa, Coast & Formative 1,000 B.C. - A.D. 750 \\
\hline PLM4 & Playa Miller-4 & 43 & $\begin{array}{l}\text { San Miguel \& } \\
\text { Gentilar }\end{array}$ & Azapa, Coast & Regional Development A.D. 1,200 - 1,350 \\
\hline AltRam & $\begin{array}{l}\text { Azapa-14, 70, } \\
\text { and } 115\end{array}$ & 72 & Alto Ramírez & Azapa, Coastal Valley & Formative 1,000 B.C. - A.D. 750 \\
\hline AZ140 & Azapa-140 & 82 & Maitas-Chiribaya & Azapa, Coastal Valley & Middle Period A.D 500 - 1,200 \\
\hline AZ6 & Azapa-6 & 45 & Cabuza & Azapa, Coastal Valley & Middle Period A.D. 500 - 1,200 \\
\hline AZ71 & Azapa-71 & 64 & Cabuza & Azapa, Coastal Valley & Middle Period A.D. 500 - 1,200 \\
\hline AZ75 & Azapa-75 & 24 & $\begin{array}{l}\text { Maitas-Chiribaya } \\
\& \text { Tiwanaku }\end{array}$ & Azapa, Coastal Valley & Middle Period A.D. 500 - 1,200 \\
\hline AZ8 & Azapa-8 & 25 & Gentilar & Azapa, Coastal Valley & Regional Development A.D. 1,350 - 1,432 \\
\hline TIW & Tiwanaku & 57 & Tiwanaku & $\begin{array}{l}\text { Isla del Sol/Tiwanaku, } \\
\text { Altiplano }\end{array}$ & Middle Period A.D. 500 - 1,200 \\
\hline
\end{tabular}


and living populations (Brewer-Carias et al. 1976; Greene 1982; Haydenblit 1996; Sofaer, et al. 1972b, 1986; Turner 1983; Wijsman and Neves 1983). Epigenetic traits have also been demonstrated to closely reflect those derived from molecular data among both humans and other nonhuman primates (Braga 2001). Such traits have the advantage of being scoreable for highly fragmented skeletal material. Given that the author of this paper scored all traits, interobserver error is not an issue. A previous study found that ranges of intraobserver error by this investigator for traits used in this study are well within recommended ranges of acceptability (Sutter 1997:162-167).

Standard data analysis procedures are used to make results presented here comparable to those presented by other nonmetric dental trait studies.
Dental trait frequencies for each mortuary sample are calculated using the 'individual count' method (Turner and Scott 1977). In cases where an individual exhibits asymmetry in the expression of a given trait the greatest level of expression is used. This scoring procedure assumes that a single genotype is responsible for any given trait's expression, and that when asymmetry exists among bilateral traits, the side exhibiting the maximum expression is closest to the true underlying genotype for the trait. The procedure also maximizes sample sizes; in cases where a given trait is observable for only one antimere but not the other, the observable side is counted as the maximum expression for that trait. This scoring procedure counts individuals for the calculation of trait frequencies.

Table 2. Nonmetric epigenetic tooth cusp and root traits scored by this study.

Rasgos epigenéticos, no métricos, de cúspides y raíces estudiados.

\begin{tabular}{|c|c|c|}
\hline Trait & Abbrev & Teeth Examined for Trait Presence \\
\hline Winging & WING & Maxillary central incisors \\
\hline Shoveling & SHOV & Maxillary and mandibular incisors and canines \\
\hline Labial Convexity & LABC & Maxillary incisors \\
\hline Double Shoveling & DSHOV & Maxillary incisors, canine, and first premolar \\
\hline Tuberculum Dentale & TD & Maxillary and mandibular canines \\
\hline Canine Distal Accessory Ridge & CDAR & Maxillary and mandibular canines \\
\hline Accesory Mesial \& Distal Cusps & UPMD & Upper premolars \\
\hline Mesial Ridge & UPMR & Upper premolars \\
\hline Metacone & META & Maxillary molars \\
\hline Hypocone & HYPO & Maxillary molars \\
\hline Metaconule & CUSP5 & Maxillary molars \\
\hline Carabelli's Trait & CARAB & Maxillary molars \\
\hline Parastyle & PARA & Maxillary molars \\
\hline Enamel Extensions & $\mathrm{EE}$ & Maxillary molars and premolars \\
\hline Upper Molar Root Number & UMRT\# & Maxillary molars \\
\hline Premolar Root Number & PMRT\# & Maxillary premolars \\
\hline Peg Shaped Tooth & PEG & Maxillary 3rd molar and lateral incisor \\
\hline Congenitally Absent Tooth & CONG & $\begin{array}{l}\text { Maxillary 3rd molar, lateral incisor, and 2nd premolar } \\
\text { Mandibular 3rd molar, 2nd premolar, and central incisor }\end{array}$ \\
\hline Odontome & ODONT & Maxillary and mandibular premolars \\
\hline Groove Pattern & PATT & Mandibular molars \\
\hline Cusp Number & CUSP\# & Mandibular molars \\
\hline Protostylid & PROTO & Mandibular molars \\
\hline Cusp 5 (Hypoconulid) & CUSP5 & Mandibular molars \\
\hline Cusp 6 (Entoconulid) & CUSP6 & Mandibular molars \\
\hline Cusp 7 (Metaconulid) & CUSP7 & Mandibular molars \\
\hline Lower Molar Root Number & LMRT\# & Mandibular molars \\
\hline Deflecting Wrinkle & DEFWR & Mandibular 1st molar \\
\hline Anterior Fovea & ANTFV & Mandibular 1st molar \\
\hline Premolar Cusp Number & LPCUSP & Mandibular premolars \\
\hline Tome's Root & TOME & Mandibular first premolar \\
\hline Canine Root Number & CRT\# & Mandibular canine \\
\hline
\end{tabular}


Prior to calculating biodistances among the samples, dental traits are eliminated from subsequent multivariate biodistance analyses -as required by the biodistance statistic used by this study-if they fail to exhibit significant contingency $\chi^{2}$ values $(p<0.05)$ according to procedures outlined by Rothhammer et al. (1984). Traits are also eliminated if fewer than 10 observations were made for more than $10 \%$ (i.e., two) of the mortuary samples examined here. Males and females are combined in order to retain acceptable $(n>10)$ sample sizes. Although dental traits have been shown to exhibit little sexual dimorphism (Scott and Turner 1997), dental traits examined by this study that are significantly related to sex as determined by $\chi^{2}$ analysis are removed from subsequent biodistance analyses. Finally, traits significantly correlated to one another are also eliminated as required for calculation of the Mean Measure of Divergence (MMD) biodistance statistic used by this study.

Prior to calculating the biodistances, dichotomized (present/absent) dental trait frequencies for each mortuary population are arcsine transformed (Greene and Myers Suchey 1976). The arcsine-transformed frequencies are used to estimate the genetic relatedness among the mortuary samples by calculating the MMD (Sjøvold 1977). The MMD is highly correlated with other measures that are commonly used in biodistance studies (Constandse-Westermann 1972; Finnegan and Cooprider 1978; Gonzalez et al. 2001a; Sokal and Sneath 1973). Importantly, the MMD can produce negative values (Greene 1982; Sjøvold 1977). This occurs when there is very little or no difference in the arcsine transformed frequencies across the traits for the two samples being compared. Negative MMDs indicate that the two mortuary samples being compared are statistically indistinguishable. The standard deviations and standardized MMDs are calculated because standardized MMD values are more appropriate when estimating biodistances among mortuary populations of different sample sizes (Sofaer et al. 1986). An MMD is statistically significant at the 0.025 level if its standardized MMD (stMMD) value is greater than 2.00 (Sjøvold 1977).

The matrix of standardized MMDs is analyzed using nonmetric multidimensional scaling (MDS) procedures. Nonmetric MDS is a useful procedure for producing easily interpretable graphical representations of complex distance matrices using the number of dimensions specified by the investigator (Kruskal 1964; Kruskal and Wish 1984). Nonmetric MDS procedures are employed by this study because they accurately reflect rank orders of dissimilarity matrices when the values are non-Euclidean, as in the case of stMMD values.

\section{Design matrices}

While stMMD values provide an indication as to the relative biological distance and associated significance among mortuary populations being compared, their interpretation is often equivocal and may not necessarily indicate which among a number of competing explanations is best supported by the resulting biodistances.

Hypothetical design matrices are developed for each of the three competing hypotheses regarding prehistoric populations dynamics in the Azapa Valley, Chile. The three competing models considered by this study include: large scale migration into the Azapa Valley population by Tiwanaku colonists (Figure 1); simple change over time due to gene flow from the adjacent altiplano (Figure 2); and, a variation on the gene flow model that hypothesizes genetic continuity among coastal populations through time, with populations of the inland valley receiving gradual genetic contributions from the adjacent altiplano (Figure 3). For hypothetical matrices designed for this study, for comparisons between samples of direct ancestral-descendant relationship, a distance of 1 represents each chronological period between the samples. If gene flow is hypothesized to have occurred, an additional 0.5 is added for the distance for each chronological period between the Azapa Valley samples being compared. When large scale Tiwanaku colonization is hypothesized, the distances for each of the two unrelated samples is traced back to the common point of origin (i.e., the Paleoindian sample) and summed. For comparisons with the Tiwanaku in the two gene flow models, Azapa Valley samples from each subsequent chronological period become more similar to the Tiwanaku by a distance of 0.5 , assuming that the gene flow was in one direction (i.e., from the altiplano into the Azapa Valley). These models are intended to be simple so as to allow for future modification when additional results and hypotheses are developed. 
Table 3. Contingency $\chi^{2}$ results for 18 nonmetric tooth and cusp traits examined by this study. Resultados de contingencia $\chi^{2}$ para los 18 dientes y rasgos no métricos de cúspide.

\begin{tabular}{lcccc}
\hline Trait & Tooth & $\chi^{2}$ & df & $p$ \\
\hline Winging & UI1 & 67.61 & 10 & 0.00 \\
Premolar Root Number & UP1 & 38.42 & 10 & 0.00 \\
Metacone & UM2 & 11.34 & 10 & 0.33 \\
Hypocone & UM2 & 11.63 & 10 & 0.31 \\
& UM1 & 10.66 & 10 & 0.38 \\
Parastyle & UM1 & 10 & 0.00 \\
Carabelli's Trait & UM1 & 9.12 & 10 & 0.52 \\
Enamel Extensions & UM2 & 23.12 & 10 & 0.01 \\
& UM1 & 18.49 & 10 & 0.05 \\
Tome's Root & LP1 & 10 & 0.08 \\
Protostylid & LM1 & 10.08 & 0.41 \\
Mandibular Cusp 7 & LM1 & 15.83 & 10 & 0.11 \\
Mandibular Root Number & LM2 & 21.09 & 10 & 0.02 \\
& LM1 & 17.56 & 10 & 0.07 \\
Odontome & Hll PM & 38.72 & 10 & 0.00 \\
Congenital Absence & UM3PCA & 22.73 & 10 & 0.01 \\
& UI2PCA & 13.74 & 10 & 0.19 \\
& LM3CA & 12.13 & 10 & 0.28 \\
\hline
\end{tabular}

Note: All italicized values are statistically significant at the .05 level.

Each of the three model matrices is then subjected to the matrix correlation technique. The matrix correlation technique is a well established and understood method commonly used in biodistance studies to test the strength of association between competing hypothetical matrices and the resulting matrix of biodistances using the Mantel test (González et al. 2001a, b; Mantel 1967; Smouse and Long 1992; Sokal et al. 1997; Waddle 1994). The Mantel test is a resampling technique that compares matrices using an arbitrary number of permutations. For the purposes of this study, 1,000 permutations are used. Results are considered significant at the 0.05 level.

\section{Results}

Among the 31 tooth and root traits examined by this study, only 18 tooth-trait combinations of the samples have at least 10 observations for $90 \%$ of the 11 mortuary populations examined. Among these 18 traits, only eight traits exhibit statistically significant differences among the 11 mortuary samples (Table 3). A more complete discussion of dental trait variability among Azapa Valley mortuary samples can be found in Sutter (1997, 2000). Among these eight traits, the enamel extensions for both the first and second maxillary molars are significantly related. Because of this, the expression for the "key" tooth (in this case, the first maxillary molar) is retained for subsequent analyses according to recommendations of Turner et al. (1991). None of the remaining seven traits' expression is associated with sex nor is intercorrelated with the other five traits. The remaining seven traits are used to calculate biodistances among the 11 mortuary samples. These seven traits, and their associated number of observations, and number of individuals exhibiting the trait are provided in Table 4.

A few trends are apparent upon inspection of the dental trait frequencies presented in Table 4. More specifically, winging of the central maxillary incisors, and peg shape and congenital absence of the maxillary third molar generally increase through time among the samples, while the protostylid of the mandibular first molar also increases through time among some of the Azapa Valley samples. There is an apparent chronological trend for enamel extensions of the maxillary first molar and root number for both the first maxillary molar and second mandibular molar, with these traits frequencies generally decreasing through time among the 11 mortuary samples examined by this study. There are no clear chronological trends for the expression of the odontome, however, this trait's expression is limited to only four of the Azapa Valley samples examined here. With the exception 
of the expression of the odontome, it can be said that there is generally an increase through time in dental trait frequencies associated with northeast Asians (i.e., sinodonty).

The Mean Measure of Divergence, its standard deviation, and standardized MMD values based upon the seven tooth and root trait combinations that significantly vary among the eleven prehistoric mortuary samples are presented in Table 5. Inspection of the stMMD indicates all biodistance comparisons with the Andean Paleoindian sample are nonsignificant. This is likely due, in part, to the composition of the sample, but may also be due to the highly variable nature of the Paleoindians as noted by numerous investigators (Jantz and Owsley 1998, 2001, 2003; Lahr 1995; Powell 1993; Powell and Neves 1999). While no clear trends are apparent for biodistance comparisons with the Paleoindian sample, it is noteworthy that the most recent Gentilar mortuary sample from Azapa- 8 is the most distinct from the Andean Paleoindians followed by the Middle Period Tiwanaku sample analyzed by this study. It is important to note that in a broader biodistance study by this investigator that examines prehistoric population dynamics in the Andes using dental trait variability for 44 prehistoric mortuary samples registered by Sutter (2005c), the Archaic Period Chinchorros are among the most similar to the Andean Paleoindians of all mortuary populations. This discrepancy is attributed to the data reduction techniques employed by MMD analyses: the MMD statistic requires that only traits that are not interrelated but that significantly vary among all of the samples be used for the calculation of biodistances. This study only used seven epigenetic dental traits whereas the broader study utilized 10 traits.

It is also apparent from biodistances presented in Table 5 that the Tiwanaku mortuary sample is the most distinct examined by this study. The Tiwanaku sample is significantly different from five of the nine Azapa Valley samples, including the Archaic Period Chinchorro, El Laucho sample from Playa Miller-7, the early Desarrollo Regional sample from Playa Miller-4, the Formative Period Alto Ramírez sample, and the Middle Period Cabuza sample from Azapa-71. Importantly, with the exception of the late Desarrollo Regional

Table 4. Seven nonmetric tooth and root traits frequencies that significantly vary among the 11 samples studied.

Frecuencia de siete rasgos no métricos de dientes y raíces que varían significativamente entre las 11 muestras estudiadas.

\begin{tabular}{|c|c|c|c|c|c|c|c|c|c|c|}
\hline \multirow{2}{*}{$\begin{array}{l}\text { Sample } \\
\text { Paleoindian }\end{array}$} & \multicolumn{2}{|c|}{ UM3PCA } & \multirow{2}{*}{$\begin{array}{c}\text { UM1EE } \\
20.0 \%(2 / 10)\end{array}$} & \multirow{2}{*}{$\begin{array}{c}\text { UP1RT } \\
100.0 \%(10 / 10)\end{array}$} & \multirow{2}{*}{$\begin{array}{c}\text { UI1WING } \\
16.7 \% \quad(2 / 12)\end{array}$} & \multirow{2}{*}{$\frac{\text { LM2RT }}{100.0 \%(10 / 10)}$} & \multicolumn{2}{|c|}{ LM1PROTO } & \multicolumn{2}{|c|}{ ULP12ODONT } \\
\hline & $0.0 \%$ & $(0 / 13)$ & & & & & $0.0 \%$ & $(0 / 8)$ & $0.0 \%$ & $(0 / 24)$ \\
\hline Chinchorro & $21.0 \%$ & $(13 / 62)$ & $19.4 \%(7 / 36)$ & $94.8 \%(55 / 58)$ & $8.1 \% \quad(5 / 62)$ & $91.2 \%(52 / 57)$ & $0.0 \%$ & $(0 / 42)$ & $0.0 \%$ & $(0 / 122)$ \\
\hline $\begin{array}{l}\text { Playa Miller-7 } \\
\text { (Laucho) }\end{array}$ & $32.7 \%$ & $(16 / 49)$ & $13.2 \%(5 / 38)$ & $97.9 \%(46 / 47)$ & $2.0 \% \quad(1 / 49)$ & $90.1 \%(20 / 22)$ & $0.0 \%$ & $(0 / 21)$ & $3.6 \%$ & $(3 / 84)$ \\
\hline $\begin{array}{l}\text { Playa Miller-4 } \\
\text { (San Miguel) }\end{array}$ & $38.5 \%$ & $(15 / 39)$ & $36.7 \%(11 / 30)$ & $97.2 \%(35 / 36)$ & $17.1 \% \quad(7 / 41)$ & $90.0 \%(18 / 20)$ & $5.0 \%$ & $(1 / 20)$ & $3.4 \%$ & $(3 / 87)$ \\
\hline Alto Ramírez & $18.6 \%$ & $(11 / 59)$ & $13.5 \%(5 / 37)$ & $94.1 \%(48 / 51)$ & $20.3 \%(12 / 59)$ & $93.9 \%(31 / 33)$ & $0.0 \%$ & $(0 / 31)$ & $0.0 \%$ & $(0 / 124)$ \\
\hline $\begin{array}{l}\text { Azapa-140 } \\
\text { (Maitas-Chiribaya) }\end{array}$ & $25.0 \%$ & $(18 / 72)$ & $10.9 \%(7 / 64)$ & $76.9 \%(40 / 52)$ & $23.3 \%(17 / 73)$ & $80.8 \%(42 / 52)$ & $1.6 \%$ & $(1 / 64)$ & $0.0 \%$ & $(0 / 242)$ \\
\hline $\begin{array}{l}\text { Azapa-6 } \\
\text { (Cabuza) }\end{array}$ & $23.1 \%$ & $(9 / 39)$ & $25.8 \%(8 / 31)$ & $80.0 \%(24 / 30)$ & $21.1 \% \quad(8 / 38)$ & $75.0 \%(18 / 24)$ & $4.2 \%$ & $(1 / 24)$ & $0.0 \%$ & $(0 / 85)$ \\
\hline $\begin{array}{l}\text { Azapa-71 } \\
\text { (Cabuza) }\end{array}$ & $8.3 \%$ & $(4 / 48)$ & $14.3 \%(5 / 35)$ & $87.5 \%(42 / 48)$ & $17.6 \% \quad(9 / 51)$ & $82.1 \%(32 / 39)$ & $0.0 \%$ & $(0 / 34)$ & $7.1 \%$ & $(7 / 99)$ \\
\hline $\begin{array}{l}\text { Azapa-75 } \\
\text { (Tiwanaku/Maitas-Chiribaya) }\end{array}$ & $6.7 \%$ & $(1 / 15)$ & $31.2 \%(5 / 16)$ & $92.3 \%(12 / 13)$ & $23.5 \% \quad(4 / 17)$ & $50.0 \% \quad(6 / 12)$ & $9.1 \%$ & $(1 / 11)$ & $0.0 \%$ & $(0 / 24)$ \\
\hline Azapa-8 (Gentilar) & $31.8 \%$ & $(7 / 22)$ & $11.1 \%(2 / 18)$ & $62.5 \%(10 / 16)$ & $39.1 \% \quad(9 / 23)$ & $85.7 \%(18 / 21)$ & $0.0 \%$ & $(0 / 17)$ & $1.6 \%$ & $(1 / 64)$ \\
\hline Tiwanaku & $19.0 \%$ & $(8 / 42)$ & $5.0 \%(1 / 20)$ & $72.2 \%(26 / 36)$ & $65.8 \%(25 / 38)$ & $83.3 \%(15 / 18)$ & $0.0 \%$ & $(0 / 12)$ & $0.0 \%$ & $(0 / 58)$ \\
\hline
\end{tabular}


Table 5. The Mean Measure of Divergence, its standard deviation, and the standardized Mean Measure of Divergence for 11 samples studied.

Resultados de la Media principal de Divergencia, su desviación estándar y la Medida Media estandarizada de Divergencia para 11 muestras estudiadas.

\begin{tabular}{|c|c|c|c|c|c|c|c|c|c|c|c|}
\hline & Paleo & Chinch & PLM7 & PLM4 & AltRam & AZ140 & AZ6 & AZ71 & AZ75 & AZ8 & Tiwanaku \\
\hline Paleoindian & - & & & & & & & & & & \\
\hline Chinchorro & $\begin{array}{l}0.07 \\
0.14 \\
0.48\end{array}$ & - & & & & & & & & & \\
\hline PLM7 & $\begin{array}{l}0.16 \\
0.15 \\
1.05\end{array}$ & $\begin{array}{r}0.00 \\
0.06 \\
-0.02\end{array}$ & - & & & & & & & & \\
\hline PLM4 & $\begin{array}{l}0.15 \\
0.16 \\
0.97\end{array}$ & $\begin{array}{l}0.04 \\
0.07 \\
0.62\end{array}$ & $\begin{array}{l}0.05 \\
0.07 \\
0.65\end{array}$ & - & & & & & & & \\
\hline AltRam & $\begin{array}{l}0.05 \\
0.15 \\
0.33\end{array}$ & $\begin{array}{r}-0.02 \\
0.05 \\
-0.32\end{array}$ & $\begin{array}{l}0.04 \\
0.06 \\
0.67\end{array}$ & $\begin{array}{l}0.05 \\
0.07 \\
0.78\end{array}$ & - & & & & & & \\
\hline AZ140 & $\begin{array}{l}0.10 \\
0.14 \\
0.70\end{array}$ & $\begin{array}{l}0.07 \\
0.05 \\
1.51\end{array}$ & $\begin{array}{l}0.14 \\
0.05 \\
2.58\end{array}$ & $\begin{array}{l}0.13 \\
0.06 \\
2.13\end{array}$ & $\begin{array}{l}0.03 \\
0.05 \\
0.64\end{array}$ & - & & & & & \\
\hline AZ6 & $\begin{array}{l}0.04 \\
0.16 \\
0.24\end{array}$ & $\begin{array}{l}0.07 \\
0.07 \\
1.08\end{array}$ & $\begin{array}{l}0.15 \\
0.07 \\
2.01\end{array}$ & $\begin{array}{l}0.07 \\
0.08 \\
0.85\end{array}$ & $\begin{array}{l}0.05 \\
0.07 \\
0.78\end{array}$ & $\begin{array}{r}-0.01 \\
0.06 \\
-0.16\end{array}$ & - & & & & \\
\hline AZ71 & $\begin{array}{r}-0.01 \\
0.15 \\
-0.05\end{array}$ & $\begin{array}{l}0.05 \\
0.06 \\
0.81\end{array}$ & $\begin{array}{l}0.09 \\
0.06 \\
1.39\end{array}$ & $\begin{array}{l}0.11 \\
0.07 \\
1.63\end{array}$ & $\begin{array}{l}0.02 \\
0.06 \\
0.38\end{array}$ & $\begin{array}{l}0.05 \\
0.05 \\
0.93\end{array}$ & $\begin{array}{l}0.05 \\
0.07 \\
0.66\end{array}$ & - & & & \\
\hline AZ75 & $\begin{array}{r}-0.02 \\
0.21 \\
-0.12\end{array}$ & $\begin{array}{l}0.03 \\
0.12 \\
0.24\end{array}$ & $\begin{array}{l}0.12 \\
0.12 \\
1.00\end{array}$ & $\begin{array}{l}0.01 \\
0.13 \\
0.09\end{array}$ & $\begin{array}{l}0.00 \\
0.12 \\
0.03\end{array}$ & $\begin{array}{l}0.05 \\
0.11 \\
0.45\end{array}$ & $\begin{array}{r}-0.01 \\
0.13 \\
-0.08\end{array}$ & $\begin{array}{l}0.01 \\
0.12 \\
0.09\end{array}$ & - & & \\
\hline AZ8 & $\begin{array}{l}0.25 \\
0.18 \\
1.39\end{array}$ & $\begin{array}{l}0.14 \\
0.09 \\
1.57\end{array}$ & $\begin{array}{l}0.22 \\
0.10 \\
2.23\end{array}$ & $\begin{array}{l}0.15 \\
0.10 \\
1.41\end{array}$ & $\begin{array}{l}0.07 \\
0.09 \\
0.78\end{array}$ & $\begin{array}{l}0.00 \\
0.08 \\
0.01\end{array}$ & $\begin{array}{l}0.04 \\
0.10 \\
0.40\end{array}$ & $\begin{array}{l}0.08 \\
0.09 \\
0.89\end{array}$ & $\begin{array}{l}0.09 \\
0.15 \\
0.57\end{array}$ & - & \\
\hline Tiwanaku & $\begin{array}{l}0.20 \\
0.17 \\
1.20\end{array}$ & $\begin{array}{l}0.34 \\
0.08 \\
4.30\end{array}$ & $\begin{array}{l}0.47 \\
0.09 \\
5.45\end{array}$ & $\begin{array}{l}0.36 \\
0.09 \\
3.86\end{array}$ & $\begin{array}{l}0.21 \\
0.08 \\
2.53\end{array}$ & $\begin{array}{l}0.08 \\
0.07 \\
1.12\end{array}$ & $\begin{array}{l}0.11 \\
0.09 \\
1.20\end{array}$ & $\begin{array}{l}0.18 \\
0.08 \\
2.20\end{array}$ & $\begin{array}{l}0.20 \\
0.14 \\
1.39\end{array}$ & $\begin{array}{l}0.05 \\
0.12 \\
0.43\end{array}$ & - \\
\hline
\end{tabular}

* Note: Italicized values are significant at the 0.05 level.

Gentilar sample from Azapa-8, all other stMMD comparisons with the Tiwanaku are relatively large (i.e., > 1.00) but nonsignificant. It is also noteworthy that the most similar sample to the Tiwanaku is the Gentilar sample from Azapa-8.

All biodistance values for comparisons among the Azapa Valley samples with the Archaic Period Chinchorro mortuary population are nonsignificant, although biodistances for both the Middle Period Maitas-Chiribaya sample from Azapa-140 and the late
Desarrollo Regional Gentilar sample from Azapa-8 are relatively large (i.e., >1.00). The negative MMD and stMMD values for comparisons between the Chinchorros and the subsequent Formative Period Alto Ramírez and El Laucho Playa Miller-7 samples indicate that the populations represented by these samples are statistically indistinguishable from the Chinchorros and suggest an ancestral-descendant relationship between the Chinchorro and these two Formative Period populations. 
The El Laucho sample from Playa Miller-7 produces statistically significant differences when compared to Middle Period and late Desarrollo Regional Azapa Valley samples from Azapa-140 (Maitas-Chiribaya), Azapa-6 (Cabuza), and Azapa-8 (Gentilar), while other comparisons with samples from the valley tend to be relatively large but nonsignificant. Interestingly, all biodistance values for comparisons among the Formative Period Alto Ramírez and other Azapa Valley mortuary samples are nonsignificant and relatively small (i.e., $<1.00)$. It is difficult to find any clear trends among
Azapa Valley samples of the Middle Period, except to say that these samples are more similar to the late Desarrollo Regional Gentilar sample from Azapa-8 than are the earlier Azapa Valley Archaic Period Chinchorros and Formative Period Alto Ramírez and Playa Miller-7 El Laucho samples.

The matrix of biodistance values among the 11 mortuary samples examined here were analyzed using nonmetric multidimensional scaling (MDS) procedures. The graphical representation of the first three dimensions of the MDS solution (Figure 4) accurately reflects the biodistances presented in

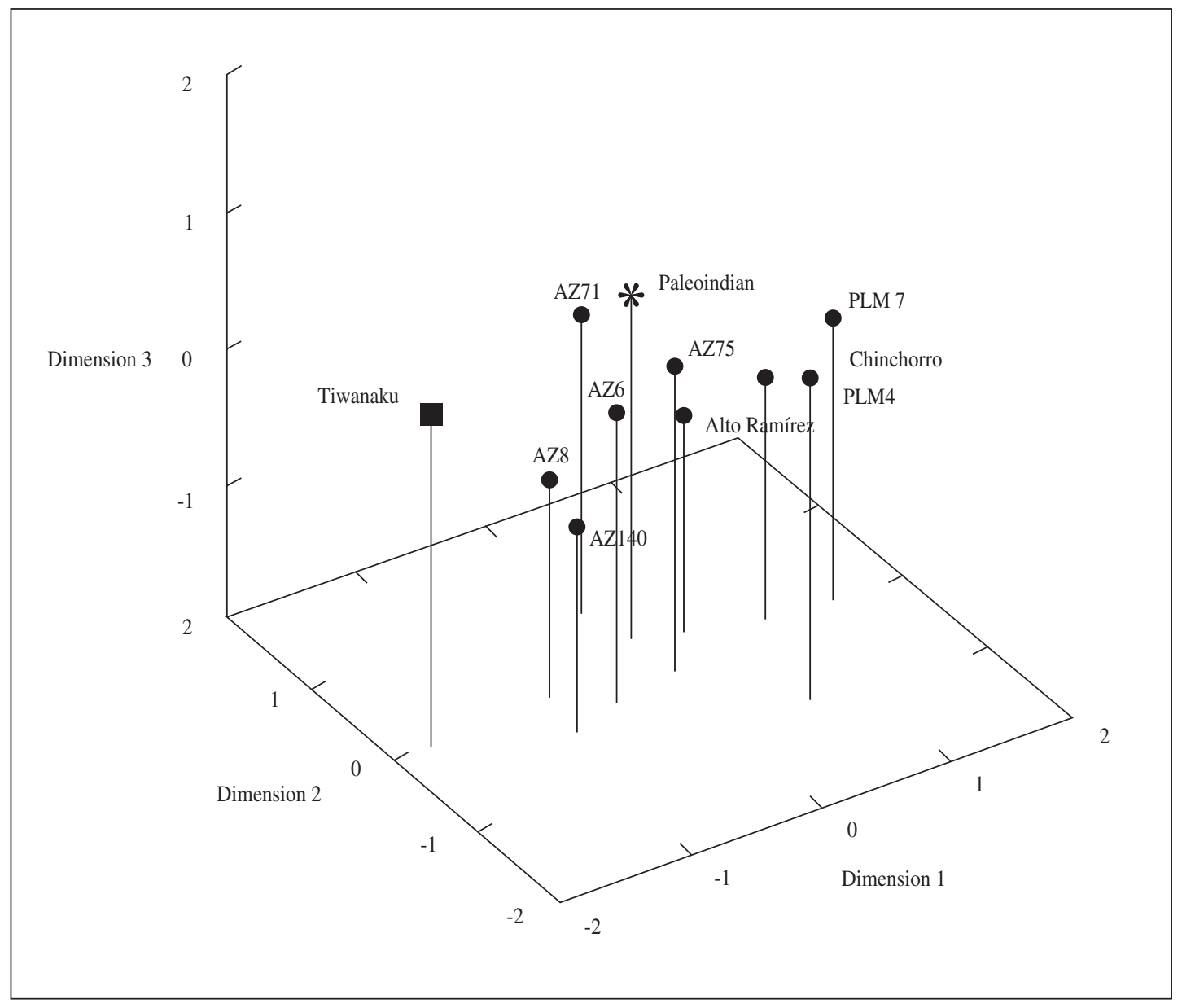

Figure 4. The 3-dimensional nonmetric multidimensional scaling solution for biodistances among eleven samples. The Tiwanaku sample is found by itself on the left side of the solution while the Andean Paleoindian and nine Azapa Valley mortuary samples are located in the middle and right side of the solution. Importantly, agricultural populations from the valley become more similar through time, while coastal samples appear together on the far right-hand side of the solution suggesting a degree of genetic coherence among the populations represented by these samples.

La muestra Paleoindia Andina y nueve del valle de Azapa se ubican en la mitad y lado derecho de la solución. Nótese que las poblaciones agricultoras del valle se van pareciendo más a través del tiempo, mientras que las costeras se agrupan en el lado derecho lejos de la solución, sugiriendo un grado de coherencia genética entre muestras poblacionales. 
Table 5 (stress $=0.047$, proportion of variance $=0.985$ ). The relatively variable nature of the Andean Paleoindian sample is reflected by its position in the middle of the solution. It is also clear that the Tiwanaku sample is distinct from all other samples analyzed by this study as indicated by its position along Dimension 1 on the left-hand side of the MDS solution. Most similar to the Tiwanaku sample as indicated by its position in multivariate space is the terminal Desarrollo Regional Gentilar sample from Azapa-8, followed by the Middle Period samples from Azapa-140, Azapa-6, Azapa-71, and Azapa-75. The next most closely related is the Formative Period Alto Ramírez sample. A small grouping of coastal mortuary samples, consisting of the Archaic Period Chinchorro, Formative Period Playa Miller-7, and early Desarrollo Regional Playa Miller-4 samples, is apparent on the right-hand side of the MDS solution.

Results of the matrix correlations between the stMMD matrix and the three hypothetical matrices provide definitive results that suggest one model performs better than the other two (Table 6). Both the Tiwanaku model, which posits large scale migration into the Azapa Valley by Middle Period Tiwanaku colonists, and the simple gene flow model -that suggests there Azapa Valley populations gradually changed over time through gene flow and local microevolutionary forcesdemonstrate a poor fit $(r=0.23)$ and nonsignificant results $(p=0.11)$ when compared to the matrix of biodistances. On the other hand, the coastal-valley divergent model -a mixed model that posits genetic continuity among the coastal populations with gradual changes among inland agricultural populations via gene flow from the altiplano- produces the best fit $(\mathrm{r}=0.43, p=0.02)$ when tested against the biodistances using the matrix correlation method. While a correlation of 0.43 for the divergent model may appear low, correlations of this magnitude are not uncommon for comparisons between hypothetical and derived biodistance matrices (González et al. 2001a, b; Sokal et al. 1997; Waddle 1994).

\section{Discussion}

Data presented by this study provide a number of unambiguous results. First, biodistance analyses indicate that none of the Middle Period Azapa Valley mortuary samples are sufficiently similar to the Tiwanaku sample to indicate a Tiwanaku colony was present in the Azapa Valley. On the contrary, with the exception of the terminal Desarrollo Regional Gentilar sample from Azapa-8, all biodistance values for comparisons among Azapa Valley mortuary samples and the Tiwanaku are either significantly different (i.e., comparisons with the Chinchorro, Playa Miller-7, Playa Miller-4, Alto Ramírez, and Azapa-71 samples) or large but nonsignificant (i.e., comparisons with Azapa-140, Azapa-6, and Azapa-75). The biodistance between the Tiwanaku and Azapa-8 samples is relatively small, but does not suggest a direct ancestraldescendant relationship between the two mortuary samples. Instead, these results suggest gradual convergence over time of populations from the interior of the Azapa Valley with the Tiwanaku that is consistent with gene flow, rather than large scale colonization by Tiwanaku colonists. These relationships are apparent both in the biodistance matrix (Table 5) and MDS solution (Figure 4). Coastal populations from the Azapa Valley region apparently maintained a degree of genetic continuity through time following the settlement of the region by the Chinchorros. These conclusions are consistent with those suggested by Sutter (1997; 1999:83; 2000:62; 2005b:193) and Sutter and Mertz (2004:139) who also report a degree of epigenetic continuity among coastal populations from the Azapa Valley using both dental and cranial traits.

In comparative studies that examine dental trait variability among 10 dental traits for 44 prehistoric Andean mortuary samples, Sutter (2005c) suggests that epigenetic changes detected in the northern Chile are likely due to gene flow associated with the increased fertility of agricultural populations in the north and east -a concept referred to as demic expansion- and that the impact of this demic expansion was dramatically reduced by decreased agricultural productivity of coastal valleys in the south central Andes. Indeed, the same Azapa Valley mortuary samples examined by this study are found to be more similar to the Andean Paleoindians and other preceramic mortuary samples from Chile, and Perú (Figure 5).

Matrix correlation analyses of the biodistance matrix against three hypothetical matrices based upon existing models of prehistoric population dynamics for the Azapa Valley provide support for these conclusions. Both the Tiwanaku colonization 


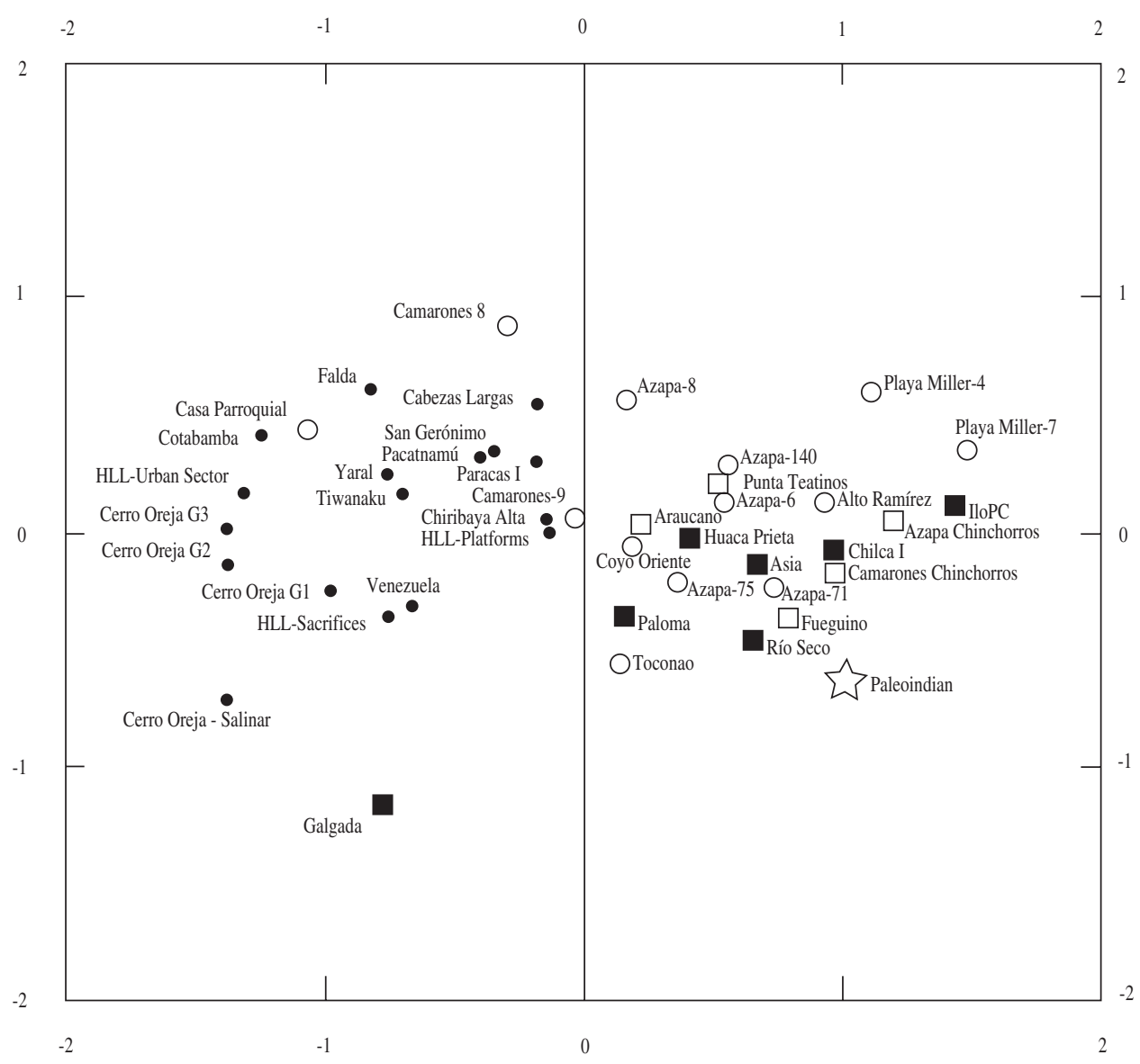

Figure 5. The 2-dimensional nonmetric multidimensional scaling solution for biodistances among 44 Andean mortuary samples (from Sutter 2005c). The Andean Paleoindian sample, Peruvian Preceramic, and all but three populations from the Southern Cone are found on the right-hand side of the solution (including all samples from the Azapa Valley), while more recent agricultural samples from Venezuela and Perú are found on the left-hand side of the solution. These results imply a demic expansion of agricultural populations into the northern Andes that had limited impact on northern Chile. Importantly, the none of the Azapa Valley samples are similar to the Tiwanaku sample.

La solución de medición por escala bidimensional no métrica multidimensional para biodistancias entre 44 muestras mortuorias andinas (de Sutter 2005c). Las muestras Paleoindia Andina, precerámico peruano y todas menos tres poblaciones de Sudamérica se encuentran en el lado derecho de la solución (incluyendo todas las muestras del valle de Azapa). Las muestras de poblaciones de agricultores más recientes de Venezuela y Perú se concentran en el lado izquierdo. Estos resultados denotan una expansión demográfica de poblaciones agrícolas en el norte de los Andes que tuvo un impacto limitado en el norte de Chile. Es importante destacar que ninguna de las muestras del valle de Azapa es similar a la muestra Tiwanaku.

model and simple gene flow model demonstrate a low and nonsignificant relationship with the biodistances generated by this study (Table 6 ). The divergent model that suggests both a degree of genetic continuity among coastal populations and gradual changes among the inland populations through gene flow from the altiplano provides the best fit and is significantly related to the biodistance matrix.
Importantly, this study only considers three simple models for matrix correlation analysis. Genetic relations are rarely as simply as one imagines and there are a number of additional factors that likely influenced genetic changes through time among Azapa Valley populations. For example, what role did relations with populations from adjacent valleys have with the prehistoric inhabitants from the Azapa Valley? Did other 
Table 6. Mantel $\mathrm{r}$ correlations and their associated levels of significance for three design matrices considered by this study.

Resultados de la prueba Mantel $r$ y su correlación y significado para cada uno de los tres modelos de diseño considerados en este estudio.

\begin{tabular}{lcr}
\hline Model & Mantel r & $p$ \\
\hline Tiwanaku Colonization & 0.23 & 0.11 \\
Gene Flow & 0.23 & 0.11 \\
Coastal-Valley Divergence & 0.43 & 0.02 \\
\hline
\end{tabular}

Italicized values are significant.

coastal populations intermarry and trade with one another according to Rostworowski's (1976, 1977, 1981) model of horizontal (i.e., coastal) complementarity, thereby accounting for some of the epigenetic changes detected among the Formative Period El Laucho and early Desarrollo Regional Playa Miller-4 mortuary samples (i.e., was their gene flow along the coast that was independent of that detected into the valley from the adjacent altiplano to the east?)? Design matrices can be developed to test these models, but, unfortunately, matrix correlation techniques employed by this study do not permit us to examine these questions without comparative mortuary samples from these regions.

\section{Conclusion}

It is difficult to reconcile the results from this study with those that suggest the presence of Tiwanaku colonies in the Azapa Valley during the Middle Period. On the other hand, results presented here provide support for those investigations that posit microevolutionary forces and low levels of gene flow for time as the primary mechanism responsible for genetic changes among prehistoric inhabitants of the Azapa Valley. Both biodistance analysis and matrix correlation analyses fail to support either the Tiwanaku colonization model or simple gene flow model. Rather, the significant relationship between the dentally derived biodistances and divergent model design matrix suggest that prehistoric population dynamics within the Azapa Valley was more subtle and nuanced than suggested by either of the two aforementioned models. Instead, it appears that once the valley was settled by the Archaic Period Chinchorro, this population divided along economic lines with Formative period coastal populations specialized in fishing, while some of the Chinchorro moved inland and became dedicated to practicing agriculture. Subsequently, each of these two Formative Period populations followed slightly different trajectories, with inland populations receiving low levels of gene flow from adjacent altiplano populations from the east, while coastal groups demonstrated a relative degree of genetic continuity relative to their inland neighbors.

It may also be that -if present- any Middle Period Tiwanaku colonies that may have been present in the Azapa Valley are not represented by the mortuary samples analyzed by this study. Indeed, based upon his survey of inland sites, Goldstein (1995) suggests that small Tiwanaku colonies may have existed at the Azapa Valley sites Atoca-1 and Quebrada del Diablo. Human remains are not available for either of these two sites. Importantly, results from this study do not deny the possible existence of altiplano colonists -it is likely that some prehistoric highlanders did, indeed, migrate to the Azapa Valley. Techniques employed by this study, however, do not permit the identification of individuals, but instead use mortuary samples as the unit of study. Other investigators are currently investigating prehistoric migration patterns using strontium isotopes that may eventually provide additional information on prehistoric migratory patterns for the Azapa Valley (Knudson 2004; Knudson et al. 2004). Rather than representing definitive results, the conclusions of this study are preliminary. It is hoped that results presented by this study will provide alternative lines of inquiry and new perspectives on the prehistoric population dynamics of the Azapa Valley.

Acknowledgments: My research in Chile was financially supported by a Fulbright Fellowship. Research in Peru was supported, in part, by a National Science Foundation grant BSN 8920769 obtained by Jane Buikstra and National Science Foundation grant 9816958 secured by me. I thank my many friends and colleagues of the Museo Arqueológico San Miguel de Azapa, Chile. The Museo Arqueológico San Miguel de Azapa of the Universidad de Tarapacá provided key facilities and 
logistic support for my research in Chile. I am grateful to my many colleagues who allowed me to examine unpublished site reports, field notes and/ or skeletal and artifact collections, particularly Ivan Muñoz, and the late Guillermo Focacci. This manuscript greatly benefited from conversations I had with Mariela Santos, Luis Briones, Juan Chacama, Liliana Ulloa, Paul Goldstein, Sonia
Guillén, Gerardo Carpio Díaz, Adán Umire, Ana Miranda Quispe, Bernardo Arriaza, Vicki Cassman, Rick Reycraft, Deborah Blom, María Cecilia Lozada, Debbie Pearsall, and the late Percy Dauelsberg and Guillermo Focacci. I also thank my wife, Claudia Encalada Santos, for editing the Spanish version of this paper's abstract. Any errors of fact or interpretation are my own.

\section{References Cited}

Álvarez, L.

1969 Un cementerio precerámico con momias de preparación complicada. Rehue 2:181-190.

Arriaza, B.T.

1994 Tipología de las momias Chinchorros: evolución de las prácticas de momificación. Chungara 26:11-24.

1995 Chinchorro bioarchaeology: chronology and mummy seriation. Latin American Antiquity 6:35-55.

Arriaza, B.T., I. Muñoz and A. Aufderheide

1993 Análisis antropológico físico de la inhumación de Acha-2. In Acha-2 y los Orígenes del Poblamiento Humano en Arica, edited by I. Muñoz, B. Arriaza and A. Aufderheide, pp. 47-62. Universidad de Tarapacá, Arica.

Bandelier, A.

1910 The Islands of Titicaca and Koati. The Hispanic Society of New York, New York.

Berenguer, J.

1978 La problemática Tiwanaku en Chile: visión retrospectiva. Revista Chilena de Antropología 1:17-40.

Berenguer, J. and P. Dauelsberg

1989 El Norte Grande en la órbita de Tiwanaku. In Culturas de Chile Prehistoria: desde sus Orígenes hasta los Albores de la Conquista, edited by J. Hidalgo, V. Schiappacasse, H. Niemeyer, C. Aldunate and I. Solimano, pp. 129-180. Andrés Bello, Santiago.

Berenguer, J., O. Espoueys and J.L. Martínez

1988 Acerca de los materiales 'Loreto Viejo' de Arica y la colonización del valle de Azapa por Tiwanaku. Paper presented at the XI Congreso Nacional de Arqueología Chilena, Santiago.

Berenguer, J.R., V. Castro and O. Silva

1980 Reflexiones acerca de la presencia de Tiwanaku en el norte de Chile. Estudios Arqueológicos 5:81-94.

Berry, A.C.

1978 Anthropological and family studies on minor variants of the dental crown. In Development, Function and Evolution of Teeth, edited by P.M. Butler and K.A. Joysey, pp. 81-98. Academic Press, New York.

Biggerstaff, R.H.

1970 Morphological variations for the permanent mandibular first molars in human monozytoic and dizygotic twins. Archives of Oral Biology 15:721-730.

1973 Heritability of the Carabelli cusp in twins. Journal of Dental Research 52:40-44.
Bird, J.B.

1943 Excavations in northern Chile. American Museum of Natural History Anthropological Papers. Vol. XXXVIII (IV):173-318.

Braga, J.

2001 Cranial discrete variation in the great apes: new prospects in palaeoprimatology. In Hominoid Evolution and Climate Change in Europe: Phylogeny of the Neogene Hominoid Primates of Eurasia. Volume 2, edited by L. de Bonis, G.D. Koufos and P. Andrews, pp. 151-190. Cambridge University Press, Cambridge.

Brewer Carias, C.A., S. LeBlanc and J.V. Neel

1976 Genetic structure of a tribal population, the Yanomama indians. XIII. Dental microdifferentiation. American Journal of Physical Anthropology 44:5-14.

Browman, D.

1980 New light on Andean Tiwanaku. American Scientist 69:408-419.

1984 Prehispanic Aymara expansion, the southern altiplano and San Pedro de Atacama. Estudios Atacameños 7:236-252.

Cassman, V.

1997 A Reconsideration of Prehistoric Ethnicity and Status in Northern Chile: The Textile Evidence. Ph. D. Dissertation, Arizona State University, Tucson.

Cocilovo, J. and F. Rothhammer

1999 Microevolución morfológica y extinción del parentesco en asentamientos humanos prehistóricos de Valle de Azapa, Chile. Revista Chilena de Historia Natural 72:213-218.

Cocilovo, J.A., H.H. Varela, O. Espoueys and V.G. Standen 2001 El proceso microevolutivo de la población nativa antigua de Arica. Chungara 33:13-22.

Constandse-Westermann, T.S.

1972 Coefficients of Biological Distance: An Introduction to the Various Methods of Assessment of Biological Distances Between Populations, with Special Reference to Human Biological Problems. Anthropological Publications, Oosterhout N.B., Netherlands.

Dauelsberg, P.

1985 Faldas del Morro: fase cultural agro-alfarera temprana. Chungara 14:7-44.

Escobar, V., M. Melnick and P. Michael

1976 The inheritance of bilateral rotation of maxillary central incisors. American Journal of Physical Anthropology 45:109-116. 
Espoueys, O., V. Schiappacasse, M. Uribe and J. Berenguer 1994 En torno al surgimiento de la cultura Arica. Paper presented at the XIII Congreso Nacional de Arqueología Chilena, Antofagasta.

Finnegan, M. and K. Cooprider

1978 Empirical comparison of distance equations using discrete traits. American Journal of Physical Anthropology 49:39-46.

Focacci, G.

1961 Excavaciones en San Miguel de Azapa. Boletines del Museo Regional de Arica, No. 6.

1969a Arqueología de Arica. Secuencia del período Agro alfarero. Horizonte tiahuanacoide. Actas del V Congreso de Arqueología Chilena, pp. 21-25. Museo Nacional de Historia Natural. Sociedad de Arqueología Chilena, Santiago.

1969b Boletas de campo: excavaciones en Playa Miller 4, 2 y6. Notes on file, Museo San Miguel de Azapa, Universidad de Tarapacá, Arica.

1974 Excavaciones en Playa Miller 7. Chungara 3:23-74.

1980 Síntesis de la arqueología del extremo norte de Chile.

Chungara 6:3-23.

1981 Nuevos fechados para la época del Tiahuanaco en la arqueología del norte de Chile. Chungara 8:63-76.

1982 Excavaciones en el cementerio de Playa Miller-9. Documentos de Trabajo 2:126-213.

1983 El Tiwanaku clásico en el valle de Azapa. Documentos de Trabajo 3:94-124.

Focacci, G.

1993 Excavaciones arqueológicas en el cementerio AZ-6 valle de Azapa. Chungara 24/25:69-124.

Focacci, G. and S. Chacón

1989 Excavaciones arqueológicas en los faldeos del Morro de Arica sitios Morro 1/6 y 2/2. Chungara 22:15-62.

Goldstein, P.

1995 Tiwanaku settlement patterns of the Azapa valley, Chile: new data and the legacy of Percy Dauelsberg. Diálogo Andino 14/15:57-74.

González, J., S. Dahinten and M. Hernández

2001a The settlement of Patagonia: a matrix correlation study. Human Biology 73:233-248.

González, J., S. Dahinten, M.A. Luis, M. Hernández and H.M. Pucciarelli

2001b Craniometric variation and the settlement of the Americas: testing hypotheses by means of R-matrix and matrix correlation analyses. American Journal of Physical Anthropology 116:154-165.

Greene, D.L.

1982 Discrete dental variations and biological distances of Nubian populations. American Journal of Physical Anthropology 58:75-79.

Greene, R.F. and J. Myers Suchey

1976 The use of inverse sine transformations in the analysis of non-metric cranial data. American Journal of Physical Anthropology 45:61-68.

Guillén, S.E.

1992 The Chinchorro Culture: Mummies and Crania in the Reconstruction of Preceramic Coastal Adaptation in the South Central Andes. Ph. D. Dissertation, University of Michigan, Ann Arbor.
Harris, E.F. and H.L. Bailit

1980 The metaconule: a morphological and familial analysis of a molar cusp in humans. American Journal of Physical Anthropology 53:349-358.

Hassanali, J.

1982 Incidence of Carabelli's trait in Kenyan Africans and Africans. American Journal of Physical Anthropology 59:317-319.

Haydenblit, R.

1996 Dental variation among four Prehispanic Mexican populations. American Journal of Physical Anthropology 100:225-246.

Jantz, R.L. and D.W. Owsley

1998 How many populations of early North Americans were there? American Journal of Physical Anthropology Supplement 26:128.

2001 Variation among early North American crania. American Journal of Physical Anthropology 114:146-155.

2003 Reply to Van Vark et al.: is European Upper Paleolithic cranial morphology a useful analogy for early Americans? American Journal of Physical Anthropology 121:185-188.

Knudson, K.J.

2004 Tiwanaku Residential Mobility in the South Central Andes: Identifying Archaeological Human Migration Through Strontium Isotope Analysis. Ph. D. Dissertation, University of Wisconsin at Madison.

Knudson, K.J., T.D. Price, J.E. Buikstra and D.E. Blom 2004 The use of strontium isotope analysis to investigate Tiwanaku migration and mortuary ritual in Bolivia and Peru. Archaeometry 46:5-18.

Kolata, A.

1993 The Tiwanaku: Portrait of an Andean Civilization. Blackwell, Cambridge.

Kruskal, J.B.

1964 Multidimensional scaling by optimizing goodness of fit to a nonmetric hypothesis. Psychometrika 29:1-27.

Kruskal, J.B. and M. Wish

1984 Multidimensional Scaling. Sage Publications, Newbury Park.

Lahr, M.M.

1995 Patterns of modern human diversification: implications for Amerindian origins. Yearbook of Physical Anthropology 38:163-198.

Lumbreras, L.G.

1972 Sobre la problemática arqueológica de Arica. Chungara 1:27-29.

Mantel, N.

1967 The detection of Disease clustering and a generalized regression approach. Cancer Research 27:209-220.

Moraga, M., E. Aspillaga, C. Santoro, V. Standen, P. Carvallo and F. Rothhammer

2001 Análisis de ADN mitocondrial en momias del norte de Chile avala hipótesis de origen amazónico de poblaciones andinas. Revista Chilena de Historia Natural 74:719-726.

Moraga, M.L., C.M. Santoro, V.G. Standen and F. Rothhammer 2005 Microevolution in prehistoric Andean populations: chronological mtDNA variation in the desert valleys of northern Chile. American Journal of Physical Anthropology 127:170-181.

Mostny, G.

1944 Excavaciones en Arica. Boletín del Museo Nacional de Historia Natural 22:135-145. 
Mujica, E.

1985 Altiplano-coast relationships in the south-central Andes: from indirect to direct complementarity. In Andean Ecology and Civilization, edited by S. Masuda, I. Shimada and C. Morris, pp. 103-140. University of Tokyo Press, Tokyo.

Mujica, E., M. Rivera and T. Lynch

1983 Proyecto de estudio sobre la complementariedad económica Tiwanaku en los valles occidentales del centrosur andino. Chungara 11:85-109.

Muñoz, I.

1981 Investigaciones arqueológicas en los túmulos funerarios del valle de Azapa (Arica). Chungara 6:57-95.

1982 La Capilla-4: una ocupación tardía en la costa de Arica. Documentos de Trabajo 3:95-125.

1983 La fase Alto Ramírez en los valles del extremo norte de Chile. Documentos de Trabajo 3:3-42.

1989 El período Formativo en el Norte Grande (1.000 a.C. a 500 d.C.). In Culturas de Chile Prehistoria: Desde sus Orígenes Hasta los Albores de la Conquista, edited by J. Hidalgo, V. Schiappacasse, H. Niemeyer, C. Aldunate and I. Solimano, pp. 107-128. Andrés Bello, Santiago.

1993 Spatial dimensions of complementary resource utilization at Acha-2 and San Lorenzo. In Domestic Architecture, Ethnicity, and Complementarity in the SouthCentral Andes, edited by M.S. Aldenderfer, pp. 94-102. University of Iowa Press, Iowa City.

Muñoz, I. and G. Focacci

1985 San Lorenzo: testimonio de una comunidad de agricultores y pescadores postiwanaku en el valle de Azapa (Arica-Chile). Chungara 15:7-30.

Murra, J.V.

1967 La visita de los Chupachu como fuente etnológica. In Visita de la Provincia de León de Huánuco en 1562, tomo 1, edited by J.V. Murra, pp. 383-406. Universidad Nacional Hermilio Valdizan, Huánuco.

1972 El "control vertical” de un máximo de pisos ecológicos en la economía de las sociedades andinas. In Visita Hecha a la Provincia de León de Huanuco en 1562: Documentos por la Historia y Etnología de Huanuco y la Selva Central 2, pp. 427-476. Universidad Nacional Hermilio Valdizan, Huánuco.

Nichol, C.R.

1989 Complex Segregation Analysis of Dental Morphological Variants. American Journal of Physical Anthropology 78:37-59.

Owen, B.

1993 A Model of Multiethnicity: State Collapse, Competition, and Social Complexity from Tiwanaku to Chiribaya in the Osmore Valley, Perú. Ph. D. Dissertation, Department of Anthropology, University of California Los Angeles.

Portin, P. and L. Alvesalo

1974 The inheritance of shovel shape in maxillary central incisors. American Journal of Physical Anthropology 41:59-62.

Powell, J.F.

1993 Dental evidence for the peopling of the New World: some methodological considerations. Human Biology 65:799-819.

1995 Dental Variation and Biological Affinity Among Middle Holocene Human Populations in North America. $\mathrm{Ph}$. D. Dissertation, Department of Anthropology, Texas
A\&M University. University Microfilms International, Ann Arbor.

Powell, J.F. and W.A. Neves

1999 Craniofacial morphology of the first Americans: Patterns and process in the peopling of the New World. Yearbook of Physical Anthropology 42:153-188.

Rivera, M.A.

1975 Una hipótesis sobre movimientos poblacionales altiplánicos y transaltiplánicos en las costas del norte de Chile. Chungara 5:7-31.

1984 Altiplano and tropical lowland contacts in northern Chilean prehistory: Chinchorro and Alto Ramírez revisited. In Social and Economic Organization in the Prehispanic Andes, edited by D.L. Browman, R.L. Burger and M.A. Rivera, pp. 143-160. vol. 194. BAR International Series, Oxford.

1991 The prehistory of northern Chile: A synthesis. Journal of World Prehistory 5:1-47.

Rivera, M.A. and F. Rothhammer

1986 Evaluación biológica cultural de las poblaciones Chinchorro. Nuevos elementos para la hipótesis de contactos transaltiplánicos: cuenca Amazonas - costa Pacífico. Chungara 16-17:295-306.

Rostworowski, M.

1976 Pescadores, Artesanos y Mercaderes Costeños en el Perú Prehispánico. Instituto de Estudios Peruanos, Lima.

1977 Coastal fishermen, merchants, and artisans in preHispanic Peru. In The Sea in the Pre-Columbian World, edited by E. Benson, pp. 167-186. Dubarton Oaks Research Library Collection, Washington, D.C.

1981 Señoríos Indígenas de Lima y Canta. Instituto de Estudios Peruanos, Lima.

Rothhammer, F., J. Cocilovo, E. Llop and S. Quevedo

1989 Orígenes y microevolución de la población chilena. In Culturas de Chile Prehistoria: Desde sus Orígenes Hasta los Albores de la Conquista, edited by J. Hidalgo, V. Schiappacasse, H. Niemeyer, C. Aldunate and I. Solimano, pp. 403-413. Andrés Bello, Santiago.

Rothhammer, F., J.A. Cocilovo and S. Quevedo

1984 El poblamiento temprano de Sudamérica. Chungara 13:99-108.

Rothhammer, F., J.A. Cocilovo, S. Quevedo and E. Llop

1983 Afinidad biológica de las poblaciones prehistóricas del litoral ariqueño con grupos poblaciones costeros Peruanos y altiplánicos. Chungara 11:161-166.

Rothhammer, F., M. Moraga, M. Rivera, C.M. Santoro,

V.G. Standen, F. García and P. Carvallo

2003 Análisis de ADNmt de restos esqueletales del sitio arqueológico de Tiwanaku y su relación con el origen de sus constructores. Chungara 35:269-274.

Rothhammer, F., S. Quevedo, A. Cocilovo, G. Focacci and

E. Llop

1982 Microevolución en poblaciones prehistóricas del área andina II. Variación craneométrica cronológica en los valles de Arica. Chungara 8:275-289.

Rothhammer, F., C. Santoro and M. Moraga

2002 Craniofacial chronological microdifferentiation of human prehistoric populations of the Azapa valley, northern Chile. Revista Chilena de Historia Natural 75:259-264.

Rothhammer, F. and C.M. Santoro

2001 El desarrollo cultural en el valle de Azapa, extremo norte de Chile y su vinculación con los desplazamientos 
poblacionales altiplánicos. Latin American Antiquity 12:59-66.

Rothhammer, F. and C. Silva

1989 Peopling of Andean South America. American Journal of Physical Anthropology 78:403-410.

1992 Gene geography of South America: testing models of population displacement based on archaeological evidence. American Journal of Physical Anthropology 89:441-446.

Santoro, C.M.

1980a Estratigrafía y secuencia cultural funeraria fases: Azapa, Alto Ramirez y Tiwanaku (Arica-Chile). Chungara 6:24-45.

1980b Fase Azapa. Transición del arcaico, al desarrollo agrario inicial en los valles bajos de Arica. Chungara 6:46-56.

1980c Formativo temprano en el extremo norte de Chile. Chungara 8:33-62.

1989 Antiguos cazadores de la Puna (9.000 a 6.000 a.C.). In Culturas de Chile Prehistoria: Desde sus Orígenes Hasta los Albores de la Conquista, edited by J. Hidalgo, V. Schiappacasse, H. Niemeyer, C. Aldunate and I. Solimano, pp. 57-80. Editorial Andrés Bello, Santiago.

1993 Complementariedad ecológica en sociedades arcaicas del área centro sur andina. In Acha-2 y los Orígenes del Poblamiento Humano en Arica, edited by I. Muñoz, B. Arriaza and A. Aufderheide, pp. 133-150. Universidad de Tarapacá, Arica.

Schiappacasse, V., V. Castro and H. Niemeyer

1989 Los desarrollos regionales en el Norte Grande (1.000 a 1.400 d.C.). In Culturas de Chile Prehistoria: Desde sus Orígenes Hasta los Albores de la Conquista, edited by J. Hidalgo, V. Schiappacasse, H. Niemeyer, C. Aldunate and I. Solimano, pp. 181-220. Andrés Bello, Santiago.

Scott, G.R.

1973 Dental Morphology: A Genetic Study of American White Families and Variation in Living South-West Indians. Ph. D. Dissertation, Arizona State University, Tempe.

1980 Population variation of Carabelli's trait. Oral Biology 52:63-78.

Scott, G.R. and C.G. Turner

1997 The Anthropology of Modern Human Teeth: Dental Morphology and its Variation in Recent Human Populations. Cambridge University Press, Cambridge.

Sjøvold, T.

1977 Non-metrical divergence between skeletal populations. The theoretical foundation and biological importance of C.A.B. Smith's mean measure of divergence. OSSA International Journal of Skeletal Research 4 (Supplement 1).

Smouse, P.E. and J.C. Long

1992 Matrix correlation analysis in anthropology and genetics. Yearbook of Physical Anthropology 35:187-213.

Sofaer, J.A., C.J. MacLean and H.L. Bailit

1972a Heredity and morphological variation in early and late developing human teeth of the same morphological class. Archives of Oral Biology 17:811-816.

Sofaer, J.A., J.D. Niswander and C.J. MacClean

1972b Population studies on southwestern indian tribes. V. Tooth morphology as an indicator of biological distance. American Journal of Physical Anthropology $37: 357-366$.
Sofaer, J.A., P. Smith and E. Kaye

1986 Affinities between contemporary and skeletal jewish and non-Jewish groups based on tooth morphology. American Journal of Physical Anthropology 70:265-275.

Søkal, R.R., N.L. Oden, J. Walker and D.M. Waddle

1997 Using distance matrices to choose between competing theories and an application to the origin of modern humans. Journal of Human Evolution 32:501-522.

Søkal, R.R. and P.H.A. Sneath

1973 Numerical Taxonomy: The Principles and Practice of Numerical Classification. W.H. Freeman, San Francisco.

Standen, V.G.

1991 El Cementerio Morro 1: Nuevas Evidencias de la Tradición Funeraria Chinchorro (Período Arcaico, Norte de Chile). Unpublished MA thesis, Departamento de Antropología, Universidad Católica de Lima, Perú.

Stanish, C. and B.S. Bauer

2004 Archaeological Research on the Islands of the Sun and Moon, Lake Titicaca, Bolivia: Final Results from the Proyecto Tiksi Kjarka. The Cotsen Institute of Archaeology at UCLA, Los Angeles.

Sutter, R.C.

1997 Dental Variation and Biocultural Affinit ies Among Prehistoric Populations from the Coastal Valleys of Moquegua, Peru, and Azapa, Chile. Unpublished Ph. D. Dissertation, University of Missouri-Columbia.

1999 The Chinchorros and their ancestors: a bioarchaeological assessment of genetic and cultural change in the Azapa valley, Chile. Journal of the Indiana Academy of Social Sciences III:77-87.

2000 Prehistoric genetic and culture change: a bioarchaeological search for pre-Inka altiplano colonies in the coastal valleys of Moquegua, Peru, and Azapa, Chile. Latin American Antiquity 11:43-70.

2005a The prehistoric peopling of South America as inferred from epigenetic dental traits. Andean Past 7:183-217.

2005b A bioarchaeological assessment of prehistoric ethnicity among early Late Intermediate period populations of the Azapa Valley, Chile. In Us \& Them: The Assignation of Ethnicity in the Andean Region: Methodological Approaches, edited by R.M. Reycraft, pp. 183 - 205. The Cotsen Institute of Archaeology, UCLA, Los Angeles.

2005c Prehistoric population dynamics in the Peruvian Andes. In The Foundations of South Highland Andean Civilization: Papers in Honor of Michael E. Moseley, edited by P.R. Williams, in press. The Cotsen Institute of Archaeology, UCLA, Los Angeles.

Sutter, R.C. and L. Mertz

2004 Nonmetric cranial trait variation and prehistoric biocultural change in the Azapa Valley, Chile. American Journal of Physical Anthropology 123:130-145.

Turner, C.G.

1983 Dental evidence for the peopling of the Americas. In Early Man in the New World, edited by R. Shutler, pp. 147157. Sage Publications, Berverly Hills.

1985 The dental search for Native American origins. In Out of Asia, edited by R. Kirk and E. Szathmary, pp. 31-78. Journal of Pacific History, Inc., Canberra. 
Turner, C.G., C.R. Nichol and G.R. Scott

1991 Scoring procedures for key morphological traits of the permanent dentition: the Arizona State University dental anthropology system. In Advances in Dental Anthropology, edited by M.A. Kelly and C.S. Larsen, pp. 13-32. WileyLiss, New York.

Turner, C.G. and G.R. Scott

1977 Dentition of Easter Island. In Orofacial Growth and Development, edited by A.A. Dahlberg and T.M. Graber, pp. 229-250. Mouton Publishers, Chicago.

Uhle, $\mathrm{M}$.

1919 Arqueología de Arica y Tacna. Boletín de la Sociedad Ecuatoriana de Estudios Históricos Americanistas 3(7-8):1-48.
Varela, H.H. and J.A. Cocilovo

2002 Genetic drift and gene flow in a prehistoric population of the Azapa valley and coast, Chile. American Journal of Physical Anthropology 118:259-267.

Waddle, D.M.

1994 Matrix correlation tests support a single origin for modern humans. Nature 368:452-454.

Wijsman, E.M. and W.A. Neves

1986 The use of nonmetric variation in estimating human population admixture: a test case with Brazilian blacks, whites, and mulattoes. American Journal of Physical Anthropology 70:395-405. 